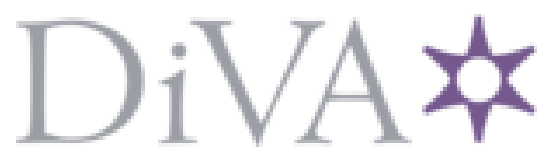

http://www.diva-portal.org

This is the published version of a chapter published in Handbook of Pre-Modern Nordic Memory Studies: Interdisciplinary Approaches.

Citation for the original published chapter:

Williams, H. (2019)

North American Perspectives: Suggested Runic Monuments

In: Jürg Glauser, Pernille Hermann \& Stephen A. Mitchell (ed.), Handbook of Pre-

Modern Nordic Memory Studies: Interdisciplinary Approaches (pp. 876-884). Berlin/

Boston: Walter de Gruyter

N.B. When citing this work, cite the original published chapter.

Permanent link to this version:

http://urn.kb.se/resolve?urn=urn:nbn:se:uu:diva-410929 


\section{II: 62 North American Perspectives - Suggested Runic Monuments}

\section{Introduction}

The most renowned runestone in the world is not found in Denmark, Norway, or Sweden, the runic heartland with over $95 \%$ of all the inscriptions. The most famous (some would say infamous) runic monument is, in fact, the Kensington stone from western Minnesota (cf. Williams 2012) (see fig. 1). It was claimed to have been found in the roots of a tree by the Swedish-American farmer Olof Ohman (Swedish Öhman) in the fall of 1898. It soon made the news and became intensely discussed among scholars as well as laymen. Almost all of the former have consistently declared the inscription to be modern, whereas a substantial number of non-academics implicitly believe that the monument is medieval. The inscription on the Kensington stone is quite sensational. It reads in translation:

Eight Götalanders and 22 Northmen on (this?) exploration/acquisition journey from Vinland westwards(?): We had a camp by two huts(?) one day's journey north from this stone. We went fishing one day. After we came home (we) found 10 men red from blood and death. Ave Maria(?), may save from evil.

There (are) 10 men by the sea to look after our ships, fourteen days' journey from this island. Year 1362.

As can be seen, several words are translated with some uncertainty, but this does not affect the general message of the text. If authentic, it would prove the presence of Scandinavians in North America more than a century before Columbus.

\section{Case study}

This is not the place to argue about the dating of the Kensington inscription; all runologists and scholars within Scandinavian linguistics unanimously conclude that it cannot be as old as its text claims. Most likely it was carved in the 1890s, and is of interest here because of its role in the memory-shaping of the Scandinavian immigrants to the United States, also true of several other American runic inscriptions.

Not many people know that as many as one hundred objects in North America have been claimed to be inscribed with runes. A full description of these 


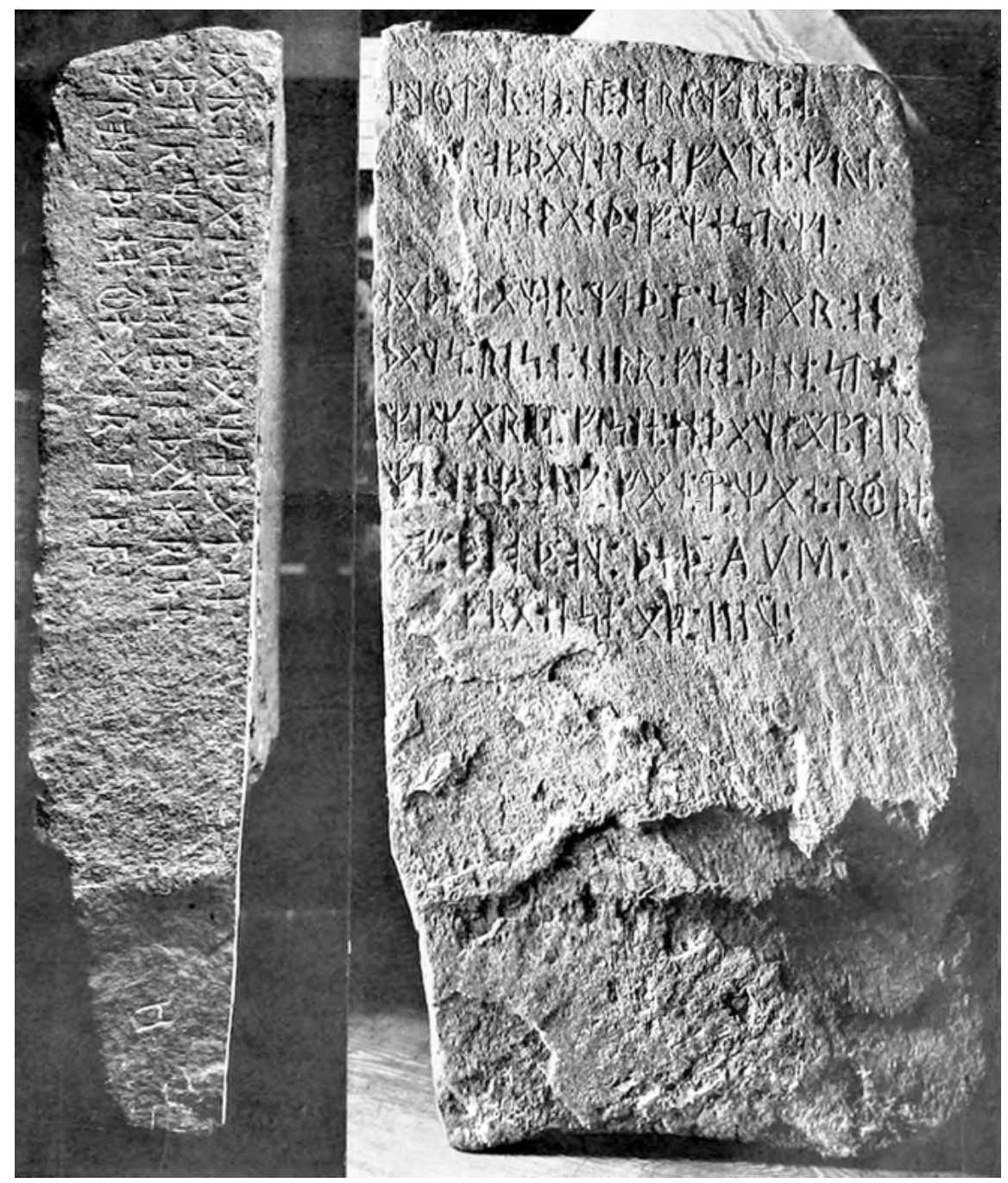

Fig. 1: Kensington stone (Alexandria, Minnesota)

is being prepared, but in this context only a concise overview, organised thematically, is offered. The material may be presented in ten groups: 1. Seek and Ye Shall Find; 2. Never was; 3. Never heard of since; 4. Mere scratches; 5. Pictographs; 6. Writing yes, but is it runic?; 7. New; 8. Fakes?; 9. Copies; and 10. Possibility or probability? 


\section{Seek and Ye Shall Find}

This group illustrates the fact that the initiative in finding runic inscriptions on American soil was not a native one, but one stemming from Scandinavians. The Danish professor Carl Christian Rafn, possibly the leading runologist of his time, and in any case a leading philologist, did his best to prove that Scandinavians were the first Europeans to colonise the New World. In his monumental and very influential work Antiqvitates Americana from 1837, soon partly made available in English, he published Old Norse texts testifying to the presence of the Northmen in America in Viking and early medieval times (see Kolodny 2012, 105-112). Among the evidence, Rafn counted the Dighton Rock in Massachusetts with its putative runes.

Rafn's theories became very popular as they served two purposes. Scandinavians were given a glorious past and domiciliary rights in the United States. Britons at the time were already enamoured with the thought that they, too, had Viking extractions (cf., e.g. Wawn 2000, 322-325), and Anglo-Americans were not slow to follow (Kolodny 2012, passim). The created memory of Viking exploits are still with us. A case in point is the Leif Erikson Day. In his proclamation, on the day before October 9, 2015, President Obama claimed to "honor [Leif Erikson] as an important piece of our shared past with the Norwegian people” (Obama 2015).

\section{Never was}

Not everyone, however, was bitten by the Viking bug and in this group may be included the prank played in 1867 by Frank Cowan on the unsuspecting inhabitants of Washington DC and the surrounding area (Tribble 2007). Cowan claimed to have unearthed the grave and runic funeral inscription of an Icelandic princess buried in 1051 near the Potomac River. The whole thing was invented and clearly meant as a lampoon directed at Professor Rafn and his followers.

\section{Never heard of since}

Representative of this category is the Deapolis Rock in North Dakota, located at the bottom of the Missouri River. In 1894 and 1934, the water level of the river was so low that a large boulder became visible, "carved with peculiar markings" (quoted from Holand 1946, 230). Hjalmar Holand (Holand 1946, 231) claimed that a government survey mark or an Indian pictograph would have been recognised by the spectators and that "[the] possibility that this disappearing rock may 
contain a runic inscription is inviting" (Holand 1946, 232). Since the community of Deapolis was founded by a Scandinavian, Herman Danielson, who was probably Swedish-American, and populated at least partly by people of Norwegian extraction (Gavett 2009, 204-206), one would rather think that runes would be quite familiar to the people examining the bolder in the riverbed.

\section{Mere scratches}

Here are to be found a number of stone objects bearing markings that have been identified as runes but are, in fact, not. Often we are dealing with natural grooves, at other times with scratches caused by damage to the stone surface by, for example, ploughing. Some markings are indeed man-made, but never meant to represent written characters, much less runes. Yet these objects and their putative runic inscriptions have played a major role in the created memory of a Viking presence, especially in New England. Olaf Strandwold (1948) was especially keen on seeing devout inscriptions on stones where no writing seems to be found (cf. Goudsward 2010, 22-23). Most of the objects found by people who think they may have acquired a runic object turn out to have natural grooves or scratches.

\section{Pictographs}

Some would-be runic monuments really do bear inscriptions but consist of pictures, not writing. An example is the Bourne stone in Massachusetts which is clearly carved by human hand. A university scholar has actually claimed that the message on the rock consists of an uninterpretable mixture of Roman and runic characters (Kirby 1993, 17-18). Another academic, however, convincingly identifies the symbols as being Native American (Pieper 2007, 331-333).

\section{Writing yes, but is it runic?}

We have at least one carving that fits this group, the Turley Hill cliff inscription near Tulsa, OK. It was considered runic and the seven symbols were thought to represent ten runes, making up a cryptogram for the date December 2, 1022 (Landsverk 1969, 58, 61). The method of runic cryptography has been debunked (cf. Haugen 1981, 155). Later, the inscription has been identified as "a South Semitic palindrome” (Farley 2007 [1994], 202), an equally improbable suggestion. It is not known what the symbols mean or if they have any linguistic sense, 
although they probably do have some significance. Two out of the seven symbols could conceivably be runes, yet the rest of the sequence proves this not to be a runic inscription.

\section{New}

In this group is found the largest number of genuine inscriptions, i.e. such that are carved with actual runes although in quite recent time. Many North Americans feel the urge to commemorate themselves or some event with a runic inscription. Thus, we have runestones erected at for example Gimli, Manitoba on the $125^{\text {th }}$ Anniversary of Islendingadagurinn (Miljure 2014) and at L'Anse aux Meadows, Newfoundland (Kalle Runristare [2016]). Private individuals are quite fond of this type of activity, too, as evidenced by a runestone erected in Escalon, CA, in memory of a living man who had his son carve the inscription (Pearson 2003).

\section{Fakes}

It is difficult to suggest members of this category for the simple fact that we do not know if a certain monument was produced to be passed off as the genuine article. The Kensington stone may be an example, but we cannot prove that. It may have been carved for pleasure or as a joke, never meant to be taken seriously. The Barrett Lake stone was indeed deemed a forgery almost immediately after discovery since it was carved with Kensington runes and thought to be dated in the same manner to 1776 or 1362 . The finder of the stone readily admitted to carving it, once someone asked him about it, and also claimed that the date was supposed to be 1876 (Sprunger 2000, 146), which in fact is also what is found on the stone. The only definite fake is the 'AVM stone' found on an island near Kensington, carved in 1985 by five doctoral students from the University of Minnesota (Williams 2002). However, even though the carvers admitted to having done it "'for fun' and to cast doubt on the validity of the nearby and famous Kensington Runestone”, they also preferred "to think it not as a hoax but as a scientific study, trying to determine whether people would think the inscription genuine" (Meier 2001). When the stone was discovered in 2001 and made the news, the carvers after all did come forward to acknowledge their handiwork. 


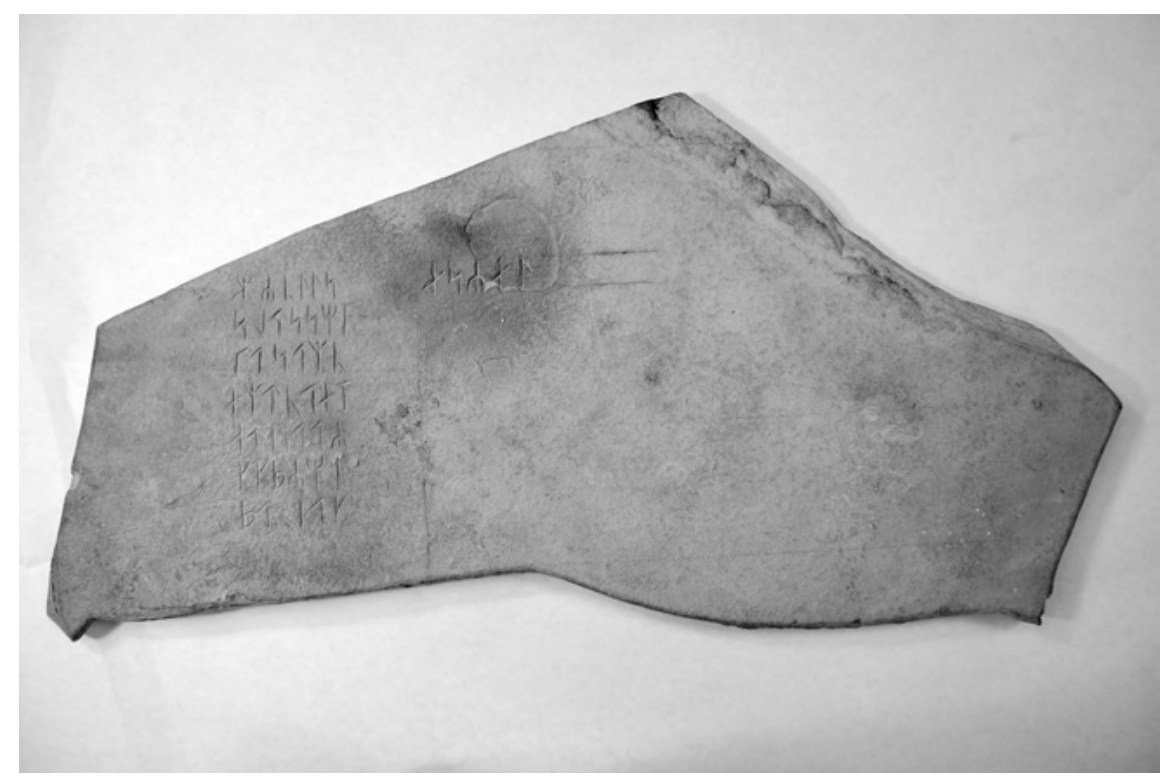

Fig. 2: San Antonio stone (San Antonio, Texas)

\section{Copies}

Less self-centred are the carvings found in this group. Copies such as these are presumably made for pure enjoyment or to honour the original inscriptions. The Mahone Bay boulder in Nova Scotia is one fine example, a (partial) copy of the famous runic rock face carving at Ramsund in the Swedish province of Södermanland (Arnold 2014). A more intriguing inscription is found on a small stone slab from San Antonio, TX, with a column and a line of strange-looking but genuine runes (see fig. 2). It took years before Jonas Nordby (Oslo) and Buford Abeldt (McKinney, Texas) figured out that what we are dealing with is a partial copy of the famous runic cryptogram Jules Verne presents in his A Journey to the Centre of the Earth (French original published in 1864, English translation in 1871). The breakthroughs were made by Nordby and Abeldt independently of each other, and neither discoverer has yet published his findings. 


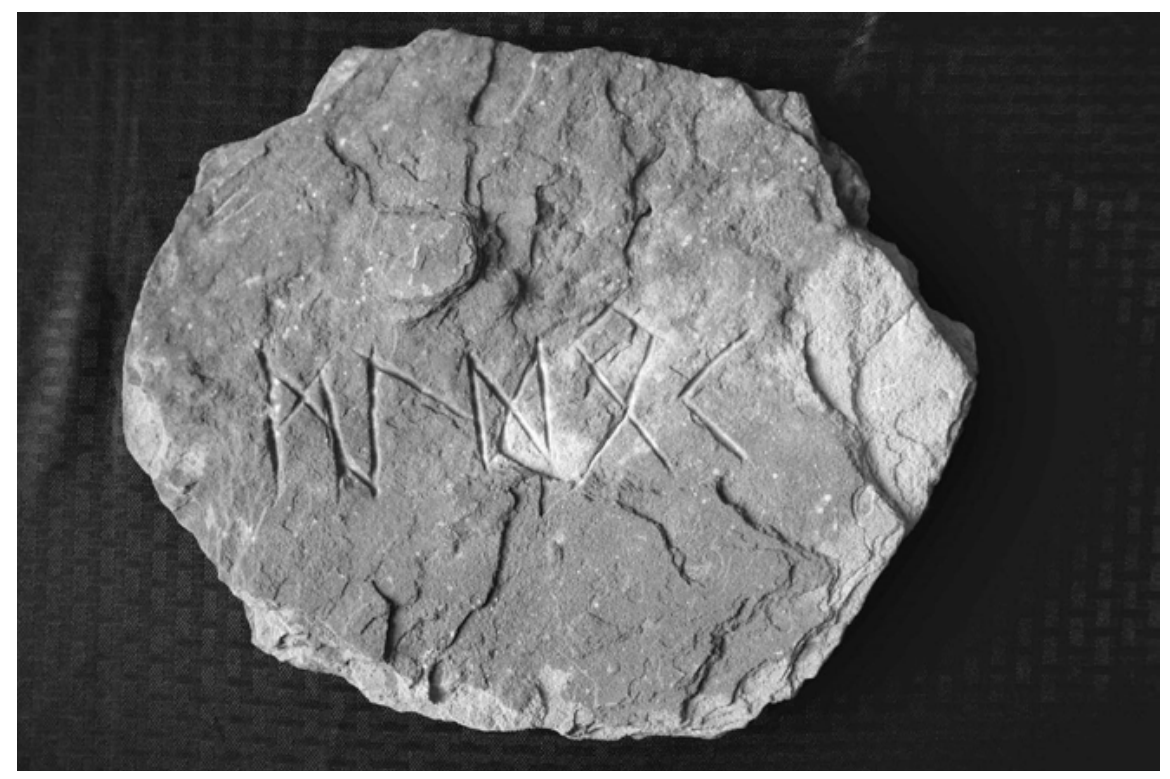

Fig. 3: Shawnee stone (Shawnee, Oklahoma) which may be connected with the Heavener stone mentioned below

\section{Possibility or probability?}

This brings us to the tenth and final group, that consisting of inscriptions with genuine runes and where there is no evidence of recent manufacture. The question here is one of possibility or probability. The best example is not the Kensington runestone but the one in Heavener, OK (Farley 2007 [1994], 217-246) (cf. fig. 3). This is a giant sandstone slab, standing upright in an isolated ravine. It bears eight very large runes of which six definitely belong to the Older, PreViking Age futhark. The likeliest reading is gnomedal which looks like a word in Modern Norwegian meaning 'valley of gnomes'. If authentic, the shape of the runes would date the inscription to before $\mathrm{AD} 700$, a time when there were no ocean-going ships in Scandinavia and long before the known Viking presence on the east coast of North America. The authenticity of the Heavener inscription has most energetically been called in question by Tompsen (2011) who advances many convincing arguments but is effectively contradicted by Torbert (2011). The discussion proves just how difficult it is to prove the age of carving in stone and how even more difficult it is to convince non-academics using scientific arguments. There will always remain a possibility that the object examined might be 
old. Admitting this while advocating that issues should be settled by probability, not possibility, might prove to be the most efficient course. A convincing case for how this inscription came about before 1923, when it was first officially reported, must also be put forward. At the time there were precious few Scandinavians in the area and no real reason for anyone to carve an inscription with common Germanic runes. The origin of the Heavener stone remains a mystery, although scientifically the conclusion must be that it was inscribed in the late nineteenth or early twentieth century.

\section{Discussion}

All runic or claimed runestones serve their purpose through the function they are given in collective memory. The Kensington stone is an especially clear example of this and has been used in all kinds of ways (Krueger 2015). Runes are intimately perceived to be Scandinavian or at least Germanic. Whether ancient or modern, they are viewed as identity markers for an immigrant population. Monuments such as the Heavener stone are claimed to evidence pre-Viking Age presence of Europeans and thus legitimising their habitation in America. Recently carved runic markers with no intent to deceive still fill the function of ethnic indicators. By re-creating such identity symbols runes are used as material in the building of an American nation, founded on Scandinavian and Anglo-Saxon presence.

\section{Works cited}

\section{Secondary sources}

Arnold, George. 2014. New Norse Runestone in Nova Scotia. Norumbega, Vinland has it Finally Been Located? https://norumbegavinland.wordpress.com/. (3 November 2017)

Farley, Gloria. 2007 [1994]. In Plain Sight. Old World Records in Ancient America. Sixth printing. Golden, CO.

Gavett, Joseph L. 2009. North Dakota. Counties - Towns \& People. Part III. Tacoma, WA.

Goudsward, David. 2010. The Westford Knight and Henry Sinclair. Evidence of a $14^{\text {th }}$ Century Scottish Voyage to North America. Jefferson, NC.

Haugen, Einar. 1981. “The Youngest Runes. From Oppdal to Waukegan.” Michigan Germanic Studies 7.1: 148-175.

Holand, Hjalmar. 1946. America 1355-1364. A New Chapter in Pre-Columbian History. New York. Kalle Runristare. [2016]. Vinland Part 1 - The Leif Eriksson Runestone. http://www. runestonecarver.com/gallery/25_vinland/vinland1/00-vinland1.html. (3 November 2017)

Kirby, Ian J. 1993. "La pierre de Bourne. Notes sur une recherche en cours.” Études de Lettres 3 , Juillet-Septembre: 7-20. 
Kolodny, Annette. 2012. In Search of First Contact. The Vikings of Vinland, the Peoples of the Dawnland, and the Anglo-American Anxiety of Discovery. Durham.

Krueger, David M. 2015. Myths of the Rune Stone. Viking Martyrs and the Birthplace of America. Minneapolis, MN.

Landsverk, O. G. 1969. Ancient Norse Messages on American Stones. Glendal, CA.

Meier, Peg. 2001. "2nd Runestone a hoax, say two who claim to have carved it." Star Tribune (Minneapolis - St. Paul) 6 November 2001.

Miljure, Ben. 2014. (Incipit) "Manitoba is home ..." CTV News Winnepeg August 3. http:// winnipeg.ctvnews.ca/vikings-come-to-gimli-for-icelandic-festival-1.1944947/comments7.543639. (3 November 2017)

Obama, Barack. 2015. Presidential Proclamation - Leif Erikson Day, 2015. https://www. whitehouse.gov/the-press-office/2015/10/08/presidential-proclamation-leif-eriksonday-2015. (3 November 2017)

Pearson, Birger A. 2003. "A California Runestone." Viking Heritage Magazine 4.03: 24.

Pieper, Peter. 2007. “'Runen' in Amerika.” In Zweiundvierzig. Festschrift für Michael Gebühr zum 65. Geburtstag. Ed. Stefan Burmeister and Jasper von Richthofen. Internationale Archäologie: Studia honoraria, 25. Rahden. 339-350.

Sprunger, David A. 2000. “Mystery \& Obsession. J. A. Holvik and the Kensington Runestone.” Minnesota History 57.3: 140-154.

Strandwold, Olaf. 1948. Norse Inscriptions on American Stones. Weehauken, NJ.

Tompsen, Lyle. 2011. "An Archaeologist Examines The Oklahoma Rune Stones.” ESOP. The Epigraphic Society Occasional Papers 29: 5-43.

Torbert, Barton J. 2011. "Reply to an Archaeologist." ESOP. The Epigraphic Society Occasional Papers 29: 44-58.

Tribble, Scott. 2007. "Last of the Vikings. Frank Cowan, Pennsylvania’s Other Great Hoaxer and a Man Who Changed History." Western Pennsylvania History, Fall: 48-57.

Wawn, Andrew. 2000. The Vikings and the Victorians. Inventing the Old North in nineteenthcentury Britain. Cambridge and Rochester, NY.

Williams, Henrik. 2002. “The 'AVM' Stone from Minnesota (Kensington II).” Nytt om runer 17 (2004): 40.

Williams, Henrik. 2012. “The Kensington Runestone. Fact and Fiction”. The Swedish-American Historical Quarterly 63.1: 3-22. 